\title{
Oxidation of the borohydride ion at silver nanoparticles on a glassy carbon electrode using pulsed potential techniques
}

\author{
V. A. Hernández-Ramírez ${ }^{\mathrm{a}}$, A. Alatorre-Ordaz ${ }^{\mathrm{a}}$, M. L. Yepez-Murrieta ${ }^{\mathrm{a}}$, J. G. Ibanez ${ }^{\mathrm{b}}$, \\ C. Ponce-de-León ${ }^{\mathrm{c}}$, F. C.Walsh ${ }^{\mathrm{c}}$ \\ ${ }^{a}$ Universidad de Guanajuato, Departamento de Química, Cerro de la Venada S/N; \\ Guanajuato, Gto. 36040, México. \\ ${ }^{\mathrm{b}}$ Universidad Iberoamericana, Prol. del Paseo de la Reforma, DF, 01219, México. \\ ${ }^{\mathrm{c}}$ School of Engineering Sciences, University of Southampton, University Road, \\ Southampton, SO17 1BJ, England.
}

\begin{abstract}
Direct oxidation borohydride fuel cells are very attractive energy conversion devices. Silver has been reported as one of the few materials which can catalyze an 8-electron oxidation. Potential step amperometric pulse techniques to synthesize nanostructured silver material on flat glassy carbon electrodes is reported and significant differences with bulk silver deposit have been observed. The oxidation of borohydride ion on the silver particles occurs at -0.025 $\mathrm{V} v s$. SCE and the potential decreases towards negative values at longer cycle times. The oxidation current also decreases with the number of cycles, suggesting that the silver active sites become partially blocked by oxidation products of borohydride. The electroactive area per unit electrode area of silver was relatively low for particles deposited using potential step amperometric techniques on glassy carbon $\left(0.002 \mathrm{~cm}^{2}\right.$ per $\left.\mathrm{cm}^{-2}\right)$ compared with the area found at a polycrystalline silver electrode $\left(0.103 \mathrm{~cm}^{2}\right.$ per $\left.\mathrm{cm}^{-2}\right)$.
\end{abstract}

\section{Introduction}

In 2005, the world energy consumption was approximately 11000 million tones of oil equivalent, with $88 \%$ obtained from fossil fuels such as oil, gas and coal with the remaining 12\% from nuclear, hydroelectric and other energy sources (1). Electrical energy from fossil fuels burning is normally generated in robust and reliable large centralized power plants, able to satisfy the energy demands of domestic and industrial activities of most countries. However, the generation of electricity by burning these primary sources of energy is inefficient and generates pollution and green house gases.

In the last half of the 20th century, fuel cells (FC) have emerged as a possible alternative for power generation at small and medium scales such as in the Gemini space flight project (2) and demonstrations of stationary applications (3). The advantage over other sources of energy, including rechargeable batteries is that FC can operate continuously as long as external fuel and oxidant reactants are supplied (4). Several FC technologies have been developed, with the proton exchange membrane fuel cell (PEMFC) using hydrogen being the most widely investigated, for its potential to generate clean energy, water and heat. 
Other fuel cells use methanol, ethanol, formic acid, hydrazine, glucose or borohydride $(5,6)$ where the efficiency of the generation of power depends on several factors such as catalyst, fuel purity, membrane material and cell design. These factors and the use of noble metals as catalysts and ion exchange membranes make the manufacture and operation of fuel cells expensive with few specialized applications (6). In the PEMFC the amount of catalyst has been gradually decreased from $4 \mathrm{mg} \mathrm{cm}^{-2}$, used in the Gemini space flights (2) down to $0.4 \mathrm{mg} \mathrm{cm}^{-2}$ or less in the 1990s (7). The catalyst requires high purity fuel, free from carbon monoxide and sulfur compounds, making the process costly and with limited applications.

Borohydride ions have been investigated for in-situ generation of clean hydrogen gas and as a direct energy source. Indirect borohydride fuel cells (IBFCs) (8) use clean hydrogen generated from the anion borohydride whereas in the direct borohydride fuel cell (DBFC) the borohydride ions are directly oxidized at the electrode surface. DBFC are attractive, because the theoretical specific energy density $\left(9.3 \mathrm{~W} \mathrm{~h} \mathrm{~kg}^{-1}\right)$ is 1.5 times larger than liquid methanol $\left(6.2 \mathrm{~W} \mathrm{~h} \mathrm{~kg}^{-1}\right)$ and 20.5 times larger than pressurized hydrogen gas $\left(0.45 \mathrm{~W} \mathrm{~h} \mathrm{~kg}^{-1}\right.$ at $\left.4500 \mathrm{psi}\right)(9,10)$.

Early studies in 1965 (11) recognised the potential of borohydride ion as a fuel and intensive research has been carried out in recent years (12-14). Various metals have been evaluated in the search for an efficient and economic catalyst to realize the 8-electron oxidation of the borohydride ion; these include: Pt (15), Pd (16), Au (17), Os (18), Ag (19-20), Cr-Ru, Ni-Ru, Pt-Ru (21) and Misch metal alloys (22).

Decomposition of the borohydride ion, resulting in hydrogen gas and metaborate ion, via hydrolysis:

$$
\mathrm{BH}_{4}^{-}+2 \mathrm{H}_{2} \mathrm{O} \rightarrow 4 \mathrm{H}_{2}+\mathrm{BO}_{2}^{-}
$$

is one of the main causes of inefficiency in the DBFC. A number of surfactants and hydrogen evolution inhibitors have been studied (23-25) as well as certain metals, notably gold and silver, which are less active for the hydrolysis reaction (1). Although the oxidation of borohydride on silver electrodes occurs at more positive potentials than on gold electrodes, silver is attractive due to its relatively lower cost ( $2 \%$ compared to gold's cost). Studies by Chatenet et al. (20) demonstrated the transfer of 7.5 electrons during the oxidation of borohydride ions at a polycrystalline silver electrode in $1 \mathrm{M} \mathrm{NaOH}$. Other studies include: use of dispersed silver nanoparticles supported on XC-72 Vulcan carbon (20) and chemical silver deposition on different carbon supports (26).

Other types of carbon with relatively high surface area such as the reticulated vitreous carbon (RVC) widely used in electrochemical reactors, have been investigated. The rigid foam structure, porosity and physicochemical properties of RVC are well suited to many electrochemical applications (27). The RVC electrodes have been incorporated in several electrochemical filter-press reactors such as the FM01-LC. This cell has been used as a direct borohydride fuel cell prototype using carbon felt electrodes coated with gold particles (17) but the cell could also be used with RVC electrodes coated with silver nanoparticles for the oxidation of borohydride ions. 
Most of the nanostructured catalyst materials used in fuel cells are chemically synthesised with strong reduction agents such as $\mathrm{NaBH}_{4}$ or hydrogen. Nanostructured materials can also be produced by electrochemical techniques. Indeed, silver nanoparticles have been reported on indium tin oxide (ITO) electrodes using a double potential step amperometry (DPSA) pulsed technique; Sandmann et al. (28) and Ueda et al. (29) showed that a nucleation pulse $\left(E_{\mathrm{n}}\right)$ of a few milliseconds, followed by a growing potential pulse $\left(E_{\mathrm{g}}\right)$ allowed to modulate the size, distribution and density of silver nanoparticles formed on ITO electrodes using cyanide bath solutions containing silver ions.

In this paper, the electrodeposition of silver nanoparticles from a non-toxic, noncyanide electrolyte solution containing silver ions is shown. The nanoparticles were electrodeposited on a flat glassy carbon electrode (GCE) disc subsequently used for the oxidation of borohydride ions in alkaline electrolyte. The different conditions of electrosynthesis cause changes in the properties and morphology of the nanostructured silver nanoparticles resulting in improved catalytic behavior during oxidation of the borohydride ion. Different behavior for the oxidation of $\mathrm{BH}_{4}{ }^{-}$was observed, depending on the polarization anodic limit of the Ag electrode, showing that different types of silver oxide that are formed in an alkaline medium influence the catalytic reaction.

\section{Experimental Conditions}

\section{Reactants and materials}

The electrolyte used for the electrodeposition of silver ions was prepared using sodium thiosulfate with sodium nitrate as stabilizing agent (30-33). The solution

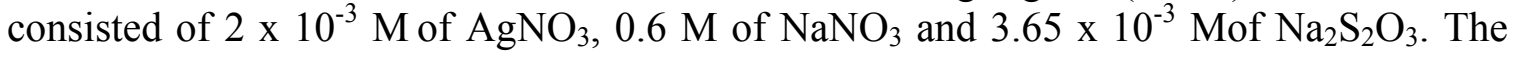
reactant $\mathrm{NaNO}_{3}$ was added as a solid salt followed by the $\mathrm{Na}_{2} \mathrm{~S}_{2} \mathrm{O}_{3}$ salt into the silver nitrate solution in the appropriate amounts to reach the above concentrations. The sequence of preparation was important to avoid disproportionation of thiosulfate which can occur at $\mathrm{pH}<6.5$ and accelerates at $\mathrm{pH}$ close to 7 in $\mathrm{AgNO}_{3}$ solution if no stabilizer $\left(\mathrm{NaNO}_{3}\right)$ is used. This solution was close to $\mathrm{pH} 8$ and was stable for 2 days, and then a light brown color is developed. Solutions of $\mathrm{NaBH}_{4}$ used for borohydride oxidation were prepared at the $10 \times 10^{-3} \mathrm{M}$ concentration in an aqueous solution of $1 \mathrm{M} \mathrm{NaOH}$. All solutions were prepared with reagent grade chemicals (Sigma-Aldrich) and deionized water.

GCE were $3 \mathrm{~mm}$ diameter discs ( $\mathrm{CH}$ Instruments) inserted in a Teflon rod and provided a geometrical area of $0.07 \mathrm{~cm}^{-2}$. The electrodes were polished in sequence with $1,0.5$ and $0.05 \mu \mathrm{m}$ alumina powder using a microporous cloth (Buhler). The polishing procedure was followed by 3 minutes of ultrasonication bath in a methanol-water mixture, to clean the surface. A bulk polycrystalline silver wire of $0.1 \mathrm{~cm}$ diameter was also used as a working electrode (Alfa Aesar). The wire was inserted on a glass tube providing a geometrical area of $7.85 \times 10^{-3} \mathrm{~cm}^{2}$ and the polishing procedure was similar to that used with the GCE. A typical three-electrode cell was used for the experiments with the flat GCE as WE and a platinised titanium mesh was used as a counter electrode. The reference electrode was situated in a separated compartment divided by a porous glass frit. All potentials were recorded against a saturated calomel reference electrode (SCE) (Tacussel) in a $0.6 \mathrm{M} \mathrm{NaNO}_{3}$ solution, in the separate compartment. 


\section{Equipment}

The silver nanoparticles were formed by application of the double potential step amperometry technique (DPSA) on the GCE working electrode. The nucleation $\left(E_{\mathrm{n}}\right)$ and the growth $\left(E_{\mathrm{g}}\right)$ potentials for the formation of silver nanoparticles were determined by cyclic voltammetry, and nucleation times $\left(t_{n}\right)$ between $50 \mathrm{~ms}$ to $1000 \mathrm{~ms}$ were explored. The growing time $\left(t_{g}\right)$ was fixed at $90 \mathrm{~s}(29)$. Cyclic voltammetry was used to study the oxidation of borohydride ions at silver particles in alkaline electrolytes, by pure diffusion. Optical micrographs were taken with an optical Leica APO-SS microscope, with an atomic force microscope (Digital Instruments) and with a scanning electronic microscope (XL30ESEM, Philips, $1 \times 10^{-5}$ mbar chamber pressure and $15 \mathrm{keV}$ electron accelerating voltage). A computer-controlled potentiostat, Princeton Applied Research (PAR) model 273A, was used with a National Instruments data-acquisition card, piloted by the MSwindows Power Suite ${ }^{\circledR} 2.56$ (PAR) software. Some electrochemical measurements were also made with an EcoChemie Autolab potentiostat (PGSTAT20) using the General Purpose, Electrochemical Software (GPES) Version 4.5.

\section{Results and Discussion}

\section{Electrodeposition of silver on a flat vitreous carbon electrode}

Figure 1A shows the cyclic voltammogram at $0.1 \mathrm{~V} \mathrm{~s}^{-1}$ of the reduction of $\mathrm{Ag}(\mathrm{I})$ ions on the flat GCE. The potential sweep started at the open-circuit potential $\left(E_{\text {ocp }}\right)$ value of $0.4 \mathrm{~V} v s$. SCE towards negative values. The curve shows a reduction process starting at $\approx$ $-0.49 \mathrm{~V} v s$. SCE corresponding to the formation of metallic silver from the negatively charged complexes $\mathrm{Ag}\left(\mathrm{S}_{2} \mathrm{O}_{3}\right)_{2}^{3-}$ :

$$
\mathrm{Ag}\left(\mathrm{S}_{2} \mathrm{O}_{3}\right)_{2}^{3-}+e^{-} \rightarrow \mathrm{Ag}^{0}+2 \mathrm{~S}_{2} \mathrm{O}_{3}^{2-}
$$

When the potential sweep reached $-0.8 \mathrm{~V} v s$. SCE the scan direction was reversed and a typical crossover, characteristic of metal nucleation and growth on a different substrate, was observed at $-0.4 \mathrm{~V} v s$. SCE followed by the anodic dissolution of metallic silver (34). The critical potential can be estimated by drawing a straight line following the increase of the cathodic current, after the thermodynamic potential of the reduction of $\operatorname{Ag}(\mathrm{I})$ ions before the peak potential. This line is illustrated on Figure 1A as -L1-. Another line, following the capacitive current from the potential at zero current indicated by line -L2 on Figure 1B can be drawn. The intersection of these two lines defines the value of the critical potential, $E_{\text {crit }}(8)$. In order to form silver nanoparticles, the application of a nucleation potential value $E_{n}$, which ensures the fixation of particles on the electrode, followed by a potential pulse has been suggested (29); $E_{n}$ values must be between 75 and $300 \mathrm{mV}$ more negative than $E_{c r i t}$. Potential values positive to $E_{c r i t}$ will not promote effective silver particle fixation because the thermodynamic oxidation of metallic silver would be favourable.

The $E_{\text {crit }}$ on the cyclic voltammogram shown on Figure 1 was $-0.395 \mathrm{~V} v s$. SCE and the silver particles should be stable at potentials negative to this value. To implant the silver metallic nuclei, a nucleation potential value $E_{n}$ of $-0.6 \mathrm{~V} v s$. SCE was selected and applied for nucleation times $t_{n}$, between 50 and $5000 \mathrm{~ms}$, to avoid the bulk silver deposition. This time determines the number and distribution of silver nanoparticles. 
Figure 1B shows a schematic representation of the potential vs. time program applied during the DPSA techniques. The program starts with the application of a conditioning potential, at the open circuit potential $\left(E_{o c p}\right)$ for a conditioning time $t_{0}$. In all cases, $t_{0}$ was fixed at $3 \mathrm{~s}$ followed by the nucleation potential $E_{n}$ for a time $t_{n}$. The growth potential $E_{g}$ is defined as the potential applied below (more positive) the critical value. This potential pulse helps to grow silver nuclei from nano- to micro-scale and the growing pulse time $t_{g}$, can vary from seconds to few minutes. In this case, $t_{g}$ was fixed at 90 seconds for the electrodeposition of silver on GCE disc and the value of $E_{g}$ was selected at $-0.3 \mathrm{~V} v s$. SCE.
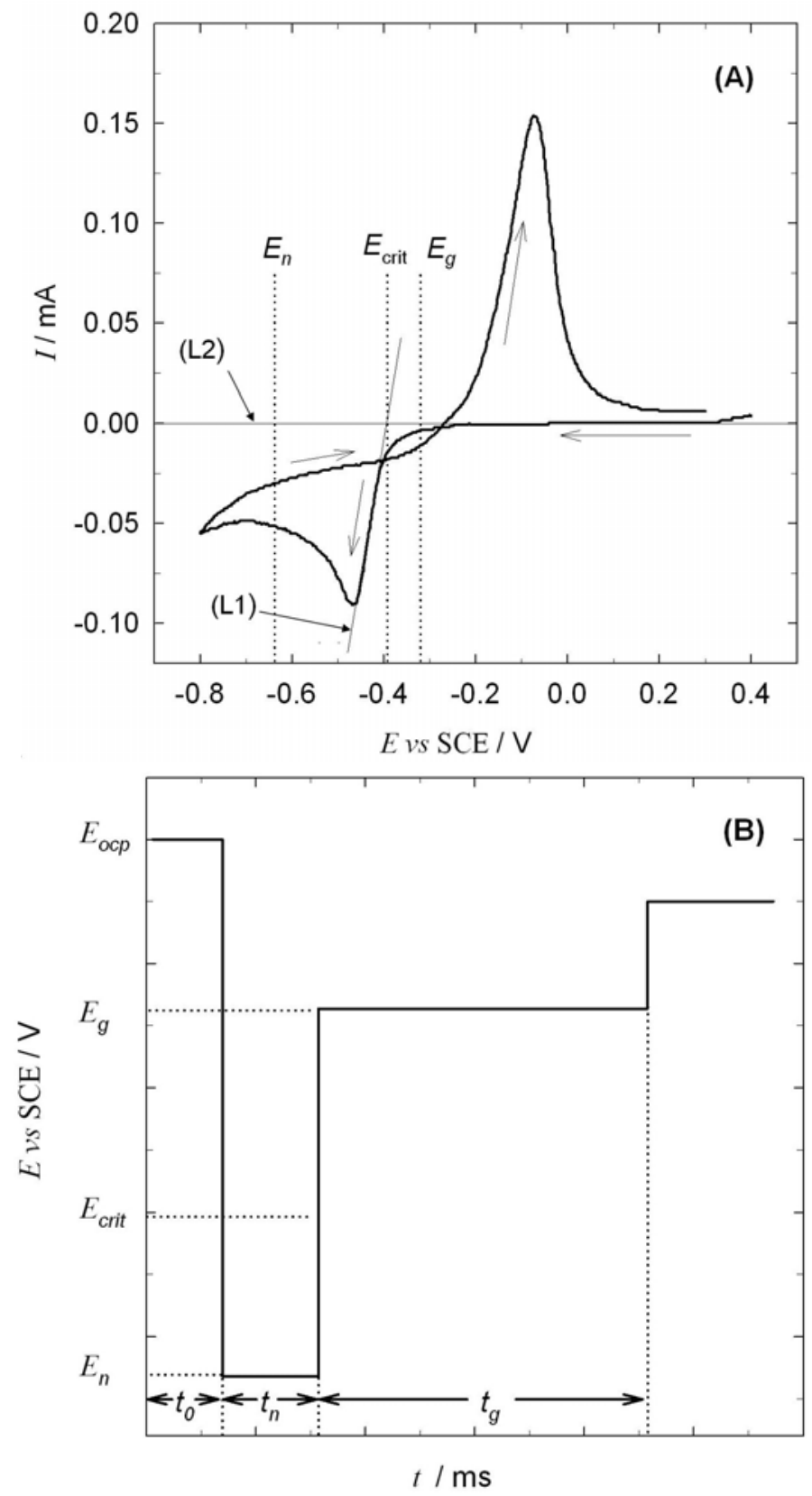

Figure 1.- (A) Cyclic voltammogram of the reduction of silver ions on a polished GCE disk of $3 \mathrm{~mm}$ diameter $\left(0.07 \mathrm{~cm}^{2}\right.$ area). The electrolyte contained $2 \mathrm{mM} \mathrm{AgNO}_{3}$ in $0.6 \mathrm{M}$ $\mathrm{NaNO}_{3}$ and $0.0365 \mathrm{M} \mathrm{Na} \mathrm{S}_{2} \mathrm{O}_{3}$. Potential sweep rate $=0.1 \mathrm{~V} \mathrm{~s}^{-1}$. (B) Schematic representation of the double-potential amperommetry pulse technique used to promote the formation of silver nanoparticles. 


\section{Electrodeposition of silver on a flat vitreous carbon electrode}

Silver nanoparticles were deposited on a GCE disc at nucleation times $t_{n}$, between 50 $\mathrm{ms}$ and $5000 \mathrm{~ms}$ at a nucleation potential $E_{n}$ of $-0.6 \mathrm{~V} v \mathrm{~s}$. SCE. A typical current $v s$. time curve for these experiments at $t_{n}$ equal to $1000 \mathrm{~ms}$ is shown in Figure 2. The initial current increased due to the charging of the double layer followed by a current decay until $300 \mathrm{~ms}$. This corresponds to a diffusion-controlled process resulting on silver nuclei, similar to the nucleation of silver on glassy carbon in ammonium hydroxide solutions by a progressive nucleation mechanism (35). Although the electrolyte in our experiments is different, the similarities in the transient curve at short times suggest similar deposition mechanism. Between $300 \mathrm{~ms}$ and $1000 \mathrm{~ms}$, the current continued to increase and is assumed that the deposition mechanism changes from progressive to bulk deposition (dendrite formation). At the end of the nucleation time when the potential step changed to the growing value $E_{g}$, $=-0.30 \mathrm{~V}$ vs. SCE, the current initially decreased followed by a steady-state behaviour.

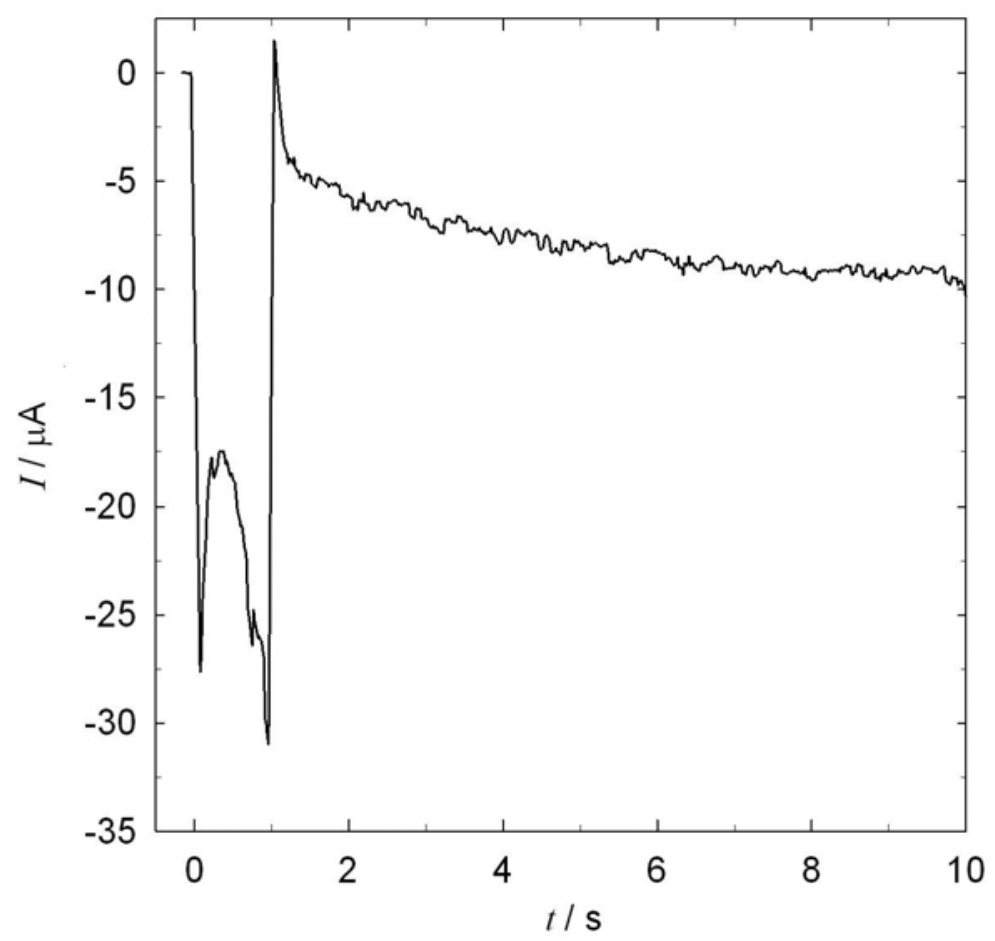

Figure 2.- Current $v s$. time response for the reduction of silver ions at a GCE $\left(0.07 \mathrm{~cm}^{2}\right.$ geometrical area) using the DPSA technique in an aqueous solution of $2 \times 10^{-3} \mathrm{M} \mathrm{AgNO}_{3}$, $0.6 \mathrm{M} \mathrm{NaNO}_{3}$ and $0.0365 \mathrm{M} \mathrm{Na}_{2} \mathrm{~S}_{2} \mathrm{O}_{3} ; E_{\mathrm{n}}=-0.6 \mathrm{~V} v s . \mathrm{SCE}, E_{\mathrm{g}}=-0.3 \mathrm{~V} v s . \mathrm{SCE}, t_{\mathrm{n}}=1 \mathrm{~s}$ and $t_{\mathrm{g}}=90 \mathrm{~s}$. Only the first 10 seconds are shown.

Figure 3A shows the image of a flat, recently polished GCE, while Figure 3B shows silver electrodeposits when a nucleation potential $E_{n}$ of $-0.6 \mathrm{~V} v s$. SCE was applied for $100 \mathrm{~ms}$ followed by a "growth" potential step at $-0.3 \mathrm{~V} v \mathrm{~s}$. SCE for $90 \mathrm{~s}$. The typical lines of the surface finish and the roughness of the surface can be appreciated in Figure $3 \mathrm{~A}$, on the order of $1 \mu \mathrm{m}$ (corresponding to the average size of the final alumina polishing particles), while in the silver electrodeposition images, conglomerates of silver metal can be observed, covering most of the electrode with a layer of fresh silver particles (Figure 3B). The agglomerated material has a particle size which varies between 1 and $5 \mu \mathrm{m}$. 
This compact and homogeneous layer was not mechanically stable; a gentle shake of the electrode in the solution results in the lost of most of the particles leaving a second and more stable inner layer of scattered particles between 20 and $100 \mathrm{~nm}$ in size, as shown in Figure 3C. SEM-EDX studies confirmed that only silver is present in the observed particles. Figure 3D shows that when $t_{n}=5 \mathrm{~s}$, dendrite structures are formed promoting bulk silver electrodeposition on the GCE surface. Analyzing the flat AFM image (Fig. $3 \mathrm{E}$ ), an estimate of the particle sizes can be obtained. In Figure 3F shows the analysis result, and the average particle diameter obtained is between 300 and $400 \mathrm{~nm}$.
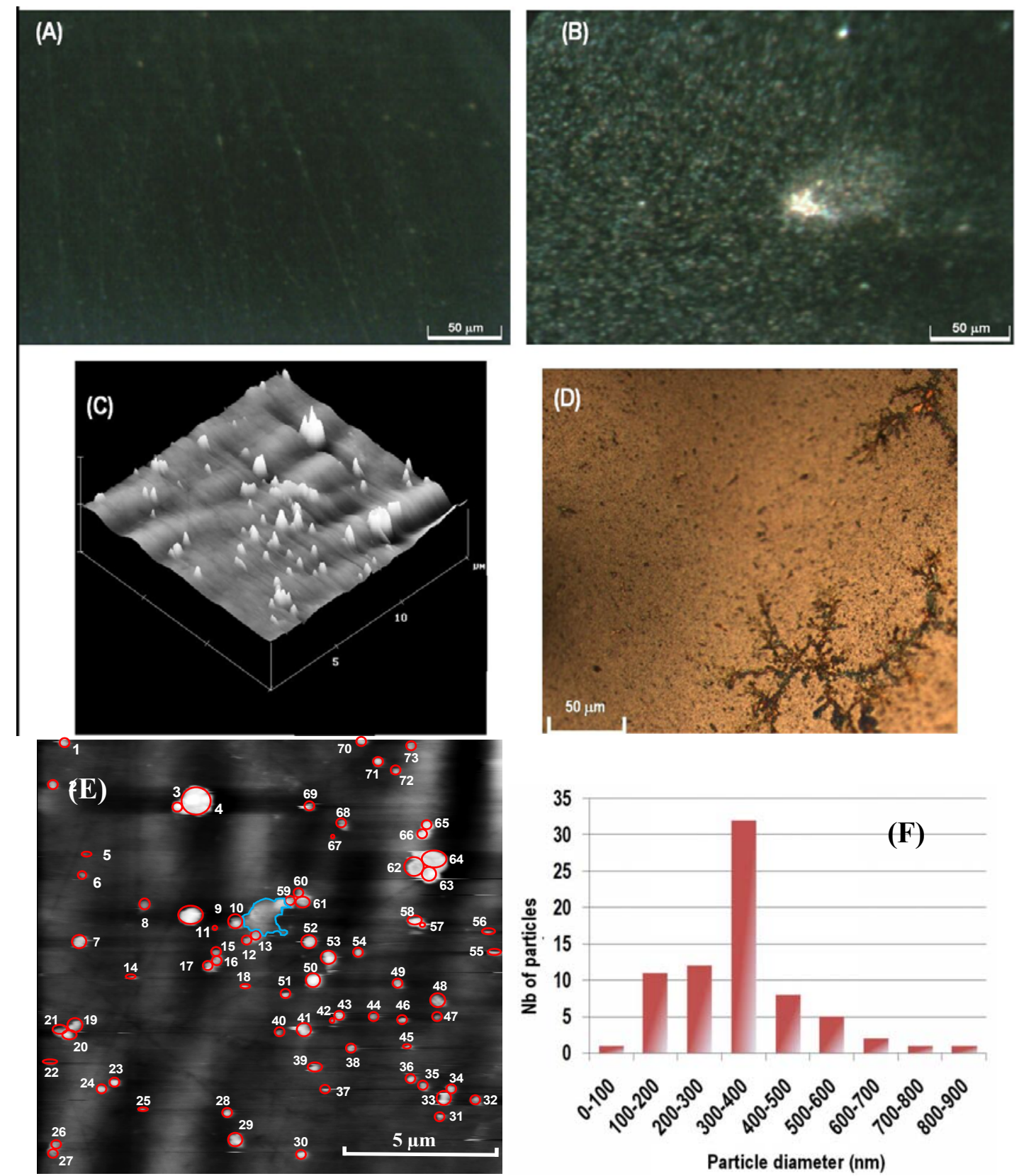

Figure 3.- Optical and AFM images of bare GCE and silver clusters deposited on a GCE according to conditions summarized in Figure 1: (A) bare GCE; (B) DPSA, $E_{\mathrm{n}}=-0.6 \mathrm{~V}$ $v s . \mathrm{SCE}, t_{\mathrm{n}}=100 \mathrm{~ms}, E_{\mathrm{g}}=-0.3 \mathrm{~V} v s . \mathrm{SCE}, t_{\mathrm{g}}=90 \mathrm{~s}$, fresh electrode; (C) the same electrode as B) after mechanical erosion of unstable layer, AFM image; (D) dendritic structures for $t_{\mathrm{n}}=5 \mathrm{~s}$; (E) flat view of AFM image showing the number of particles observed and (F) particle size distribution in E). 
Determination of the electrochemical area of metallic silver

Underpotential deposition (UPD) of lead ions on metallic silver was used to calculate the electrochemical active area of a flat polycrystalline silver electrode and silver microparticulates deposited on a glassy carbon electrode. Figure 4 shows two cyclic voltammograms of a polycrystalline silver flat electrode of geometrical area $7.85 \times 10^{-3}$ $\mathrm{cm}^{2}$ immersed in $0.5 \mathrm{M}$ of $\mathrm{CH}_{3} \mathrm{COONa}$ and $0.01 \mathrm{M}^{\circ} \mathrm{CH}_{3} \mathrm{COOH}$ solution.

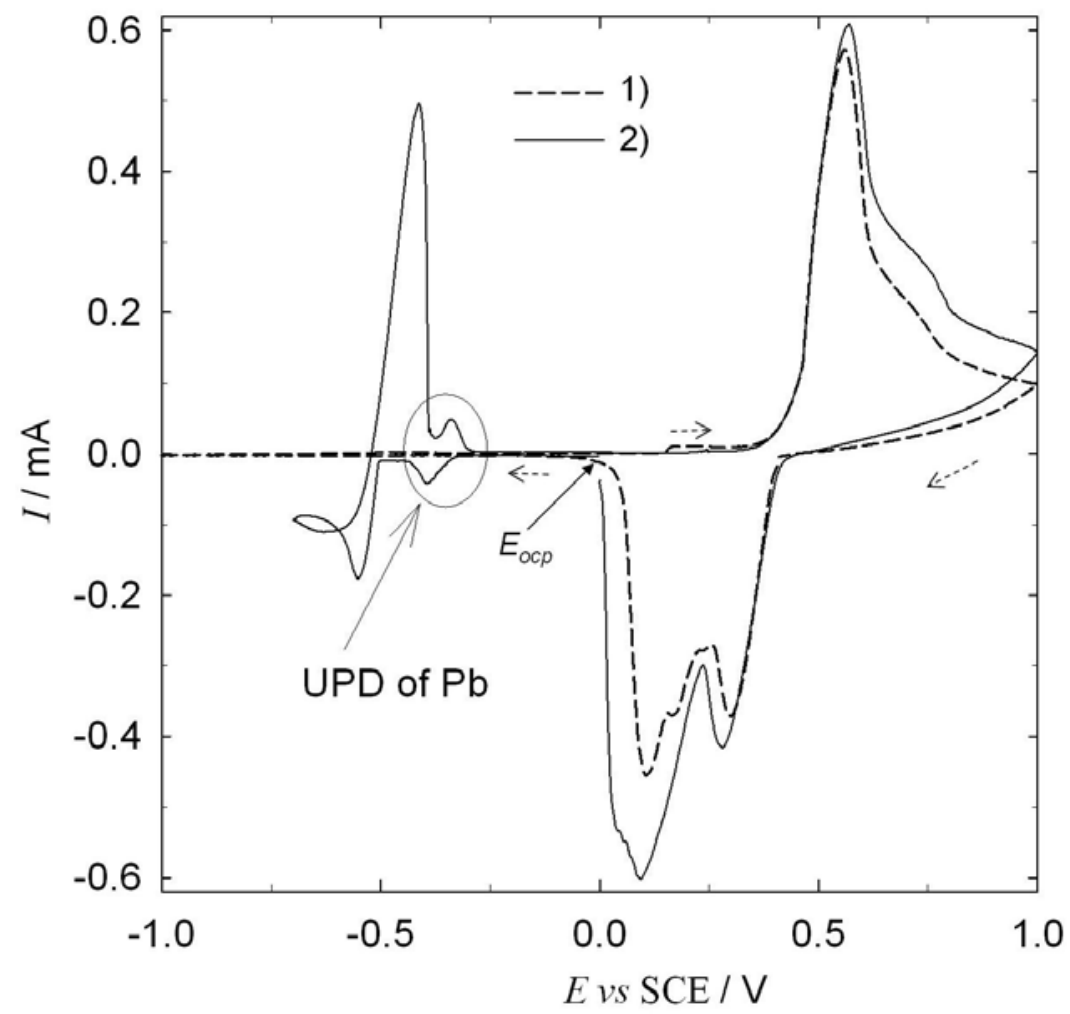

Figure 4.- Cyclic voltammogram of a polycrystalline silver electrode of $7.85 \times 10^{-3} \mathrm{~cm}^{2}$ geometrical area. Potential sweep rate $=0.01 \mathrm{~V} \mathrm{~s}^{-1}$, electrolyte: $0.5 \mathrm{M} \mathrm{CH}_{3} \mathrm{COONa}$ and $0.01 \mathrm{M}$ of $\mathrm{CH}_{3} \mathrm{COOH}$. 1) without $\left.\mathrm{Pb}, 2\right) 0.05 \mathrm{M}$ of $\left(\mathrm{CH}_{3} \mathrm{COO}\right)_{2} \mathrm{~Pb}$ present.

The Figure 4, curve 1 is the response of the electrode in this solution while the curve 2 is the response when $0.05 \mathrm{M}$ of $\left(\mathrm{CH}_{3} \mathrm{COO}\right)_{2} \mathrm{~Pb}$ was added to the solution. The two curves show the oxidation of metallic silver between 0.35 and $1.0 \mathrm{~V} v s$. SCE and the corresponding reduction reactions between 0.46 to $0.10 \mathrm{~V} v s$. SCE. When the lead acetate was added, the UPD of lead (full line) occurs between $-0.30 \mathrm{~V}$ and $-0.43 \mathrm{~V}$ vs. SCE, before the bulk deposition of lead while the oxidation occurs between $-0.385 \mathrm{~V}$ and $0.250 \mathrm{~V}$ vs. SCE, after the stripping peak in the cathodic scan. The charge under the anodic peak of the desorption of a lead monolayer from a cyclic voltammogram at $20 \mathrm{mV}$ $\mathrm{s}^{-1}$ sweep rate was $46 \times 10^{-3} \mathrm{C}$, which combined with the theoretical value of $400 \pm 20 \mathrm{x}$ $10^{-3} \mathrm{C} \mathrm{cm}^{-2}$ for the charge corresponding to full coverage of lead on silver (36) gives an electrochemical surface area $A_{e c}$ of $0.11 \mathrm{~cm}^{2}$ corresponding to approximately $14 \mathrm{~cm}^{2}$ of silver per $\mathrm{cm}^{2}$ of electrode.

The electroactive area of the silver particles deposited on a glassy carbon electrode of $0.07 \mathrm{~cm}^{2}$ geometrical area formed at nucleation time $t_{n}$, of $100 \mathrm{~ms}$ was calculated by the same procedure used above for the flat silver electrode. Figure 5 shows the cyclic 
voltammogram of the UPD lead deposition process on silver particles at a sweep potential rate of $0.2 \mathrm{~V} \mathrm{~s}^{-1}$. Experiments at lower sweep rates yielded poor peak definition. The charge under the desoption process of this curve was $1.03 \times 10^{-6} \mathrm{C}$. Considering the charge per unit area occupied by the adsorption of the lead atoms, the area of the $\mathrm{Ag}$ particles deposited on the glassy carbon electrode is $\approx 2.5 \times 10^{-3} \mathrm{~cm}^{2}$. This corresponds to around $0.035 \mathrm{~cm}^{2}$ of silver per $\mathrm{cm}^{2}$ of glassy carbon electrode.

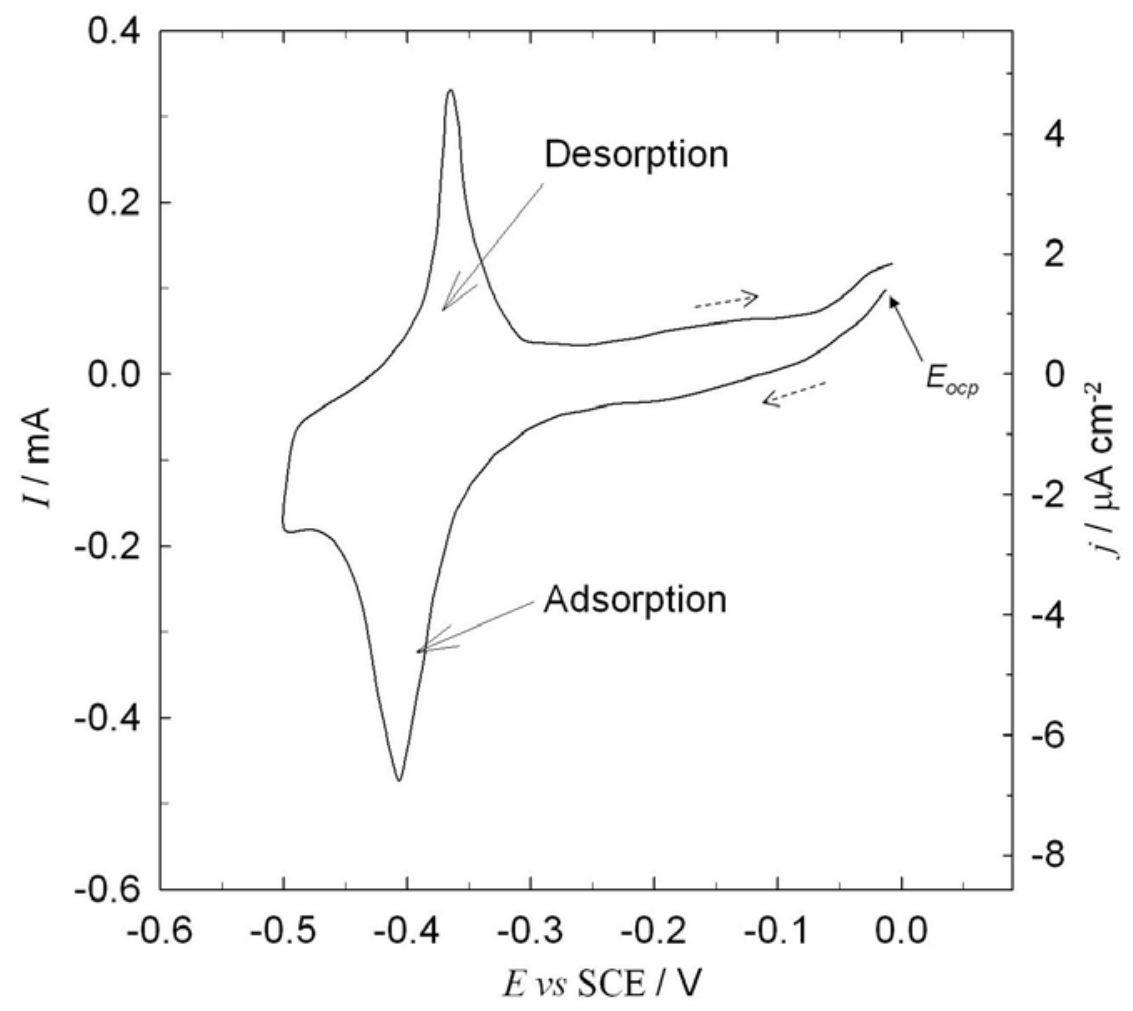

Figure 5.- Cyclic voltammogram at silver particles previously deposited on a glassy carbon electrode of $0.070 \mathrm{~cm}^{2}$ geometrical area at $0.02 \mathrm{~V} \mathrm{~s}^{-1}$ and a nucleation time, $t_{n}$ of $100 \mathrm{~ms}$, immersed in $0.5 \mathrm{M}$ of $\mathrm{CH}_{3} \mathrm{COONa}, 0.01 \mathrm{M}$ of $\mathrm{CH}_{3} \mathrm{COOH}$ and $0.05 \mathrm{M}$ of $\left(\mathrm{CH}_{3} \mathrm{COO}\right)_{2} \mathrm{~Pb}$.

\section{The oxidation of borohydride ion on silver in alkaline electrolyte}

Cyclic voltammograms with and without borohydride ions were carried out on a polycrystalline silver electrode. Figure $6 \mathrm{~A}$ shows that the oxidation of metallic silver in 1 $\mathrm{M} \mathrm{NaOH}$ solution, with no borohydride, starts at around $+0.15 \mathrm{~V} v s$. SCE (peak I) followed by two additional peaks at $+0.25 \mathrm{~V} v s$. SCE (peak II) and $+0.55 \mathrm{~V}$ (peak III) $v s$. SCE. Anodic peaks at similar potentials have also been observed in alkaline solution by Popkirov et al $(37,38)$ and have been related to the formation of an $\mathrm{Ag}_{2} \mathrm{O}$ monolayer (39) (peak I); bulk $\mathrm{Ag}_{2} \mathrm{O}$ deposition (peak II) and $\mathrm{AgO}$ (peak III). Savinova et al. (40) have reported that the adsorption of $\mathrm{OH}$ ions is carried out at potentials from - $0.8 \mathrm{~V} v s$. SCE, providing a compact layer of $\mathrm{AgOH}$. 

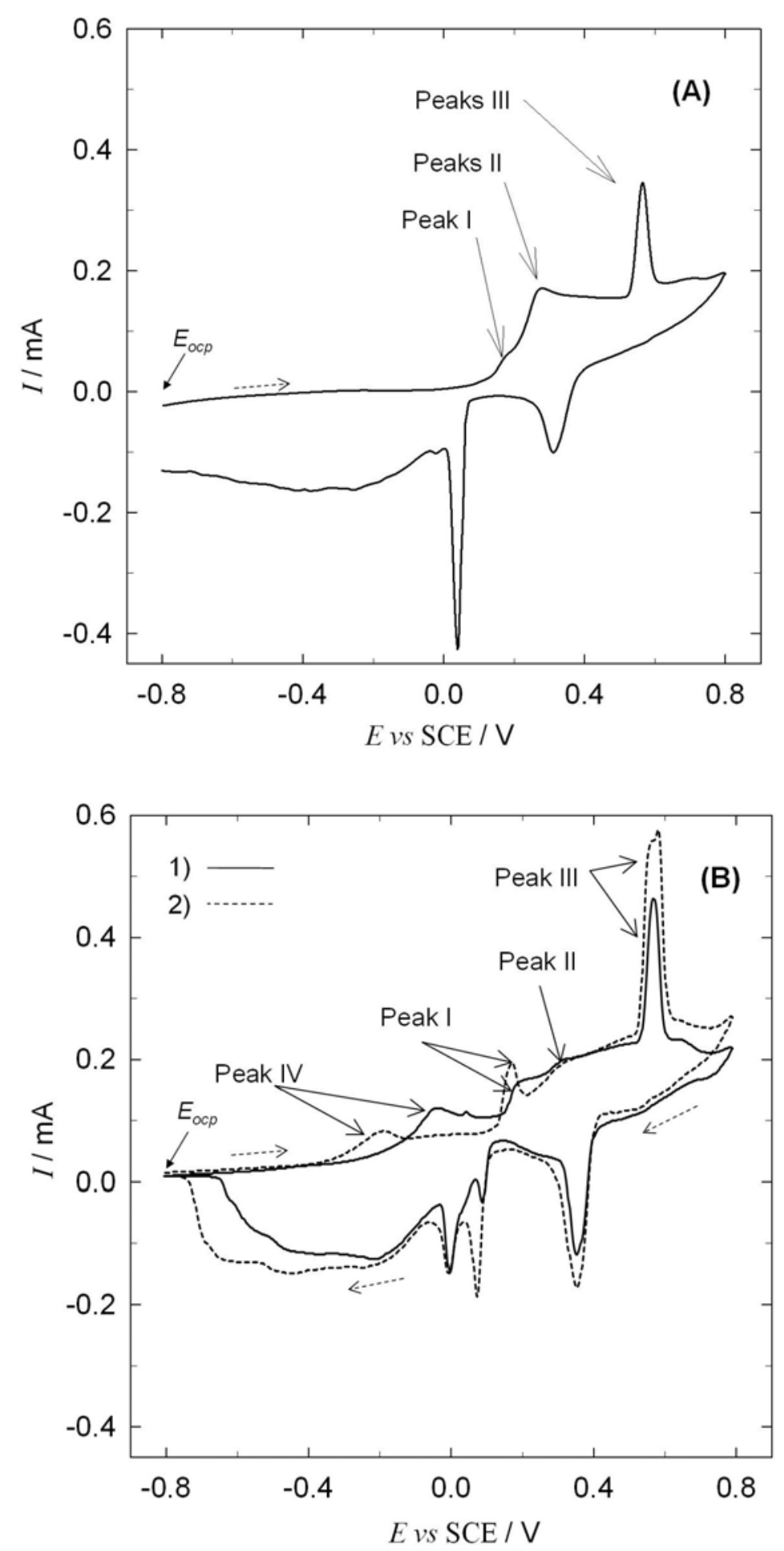

Figure 6.- Cyclic voltammograms of a polycrystalline silver electrode of $0.196 \mathrm{~mm}^{2}$ geometrical area in various electrolytes at a potential sweep rate of $0.02 \mathrm{~V} \mathrm{~s}^{-1}$. (A) $1 \mathrm{M}$ $\mathrm{NaOH}$ solution, first cycle, (B) curve 1) $1 \mathrm{M}$ of NaOH plus $10 \mathrm{mM} \mathrm{NaBH}_{4}$, first cycle and curve 2) $1 \mathrm{M}$ of $\mathrm{NaOH}$ with $10 \mathrm{mM} \mathrm{NaBH}_{4}$ third cycle.

When the cyclic voltammograms were carried out with the solution containing $10 \mathrm{x}$ $10^{-3} \mathrm{M}$ of borohydride ions in $1 \mathrm{M}$ of $\mathrm{NaOH}$ aqueous electrolyte at $0.02 \mathrm{~V} \mathrm{~s}^{-1}$ an additional oxidation peak was observed. Figure $6 \mathrm{~B}$, curve 1 shows this peak (IV) during 
the first cycle on the polycrystalline silver electrode starting at $-0.3 \mathrm{~V} v s$. SCE, with a maximum at $-0.05 \mathrm{~V} v s$. SCE. The curve also shows the oxidation peaks of silver observed in Figure 6A. On the second and consecutive cycles the potential of the peak IV shifts to $-0.2 \mathrm{~V} v s$. SCE and after the third cycle shown in Figure $6 \mathrm{~B}$ curve 2, the cyclic voltammogram no longer changed in the following cycles. The appearance of the peak IV at more negative potential values after the first cycle might be due to the fact that, although the silver oxides have been reduced, some oxide nuclei still remain on the surface as has been shown by Sandman et al. (28) and are able to catalyze the oxidation of borohydride at more negative potentials.

Fresh silver particles electrodeposited on a GCE at $t_{n}=100 \mathrm{~ms}$ by the DPSA technique, at the same conditions as in Figure 6B, were used for the oxidation of borohydride but the oxidation potential was restricted to $0 \mathrm{~V} v s$. SCE. As discussed above, metallic silver and a monolayer of $\mathrm{AgOH}$ are formed on this modified GCE. Figure 7 shows the cyclic voltammogram when no borohydride was added and the $1^{\text {st }}, 2^{\text {nd }}, 5^{\text {th }}, 10^{\text {th }}$ and $15^{\text {th }}$ cycles, curves $\mathrm{b}$, c, d and e respectively, with $10 \times 10^{-3} \mathrm{M}$ of borohydride. Although not shown in the Figure, the anodic signal on the bare GCE in this solution starts to be significant at around $+0.7 \mathrm{~V} v s$. SCE.

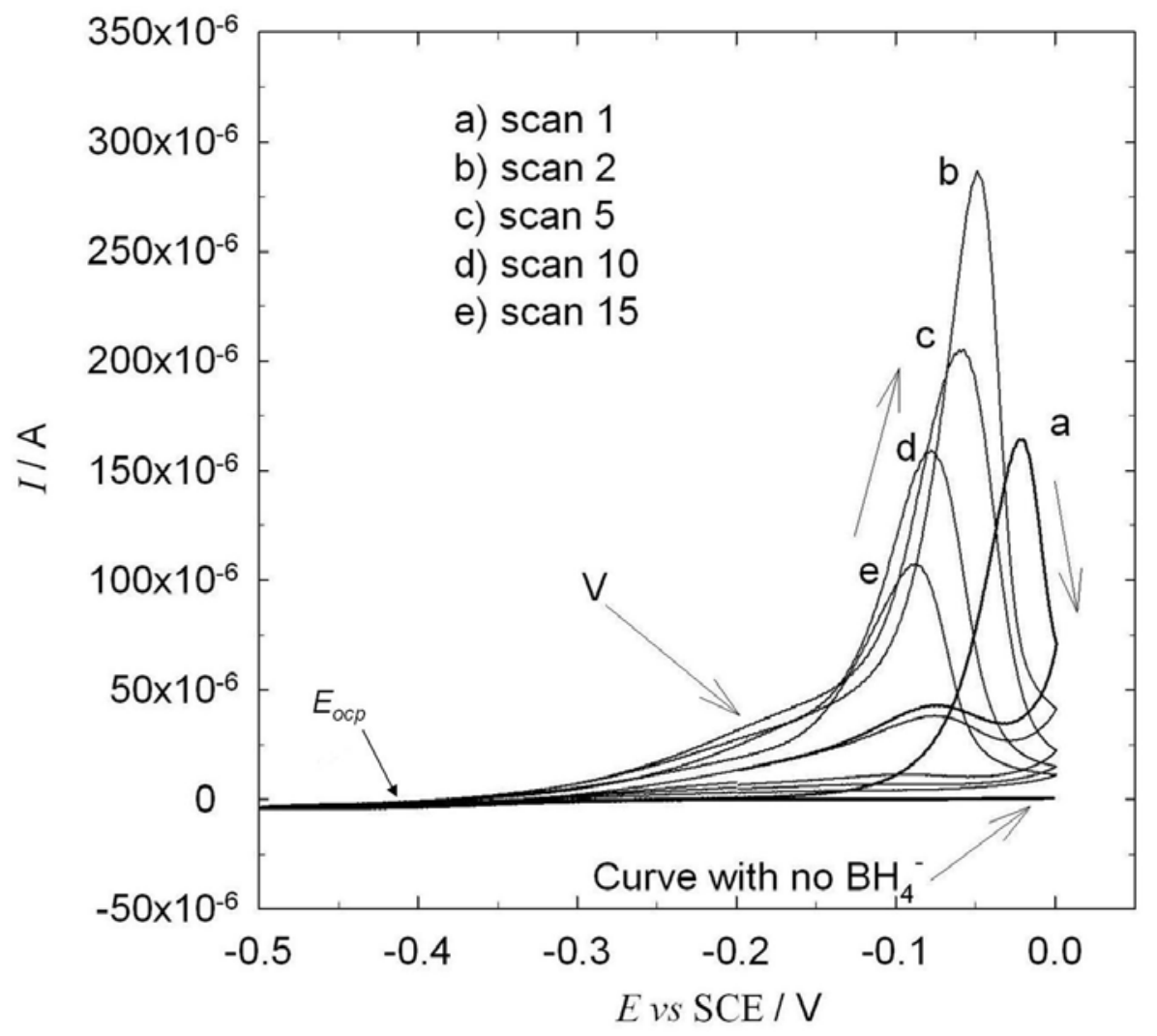

Figure 7.- Cyclic voltammograms for the oxidation of borohydride ion in an electrolyte containing $10 \times 10^{-3} \mathrm{M} \mathrm{NaBH}_{4}$ in $1 \mathrm{M} \mathrm{NaOH}$. GCE with silver clusters deposited by the DPSA technique (as reported in Figure 1B) at a nucleation time $t_{n}$ of $100 \mathrm{~ms}$ and growth time $t_{\mathrm{g}}$ of $90 \mathrm{~s}$. Potential sweep rate $=0.02 \mathrm{~V} \mathrm{~s}^{-1}$.

In all the voltammograms in Figure 7 the sweep potential started at the open-circuit value of $\approx-0.4 \mathrm{~V} v s$. SCE towards cathodic values and no cathodic process was observed; 
then the potential was reversed at $-0.5 \mathrm{~V} v s$. SCE towards anodic values. As can be seen on Figure, the catalytic behavior of the Ag-GCE changes with the number of cycles; the oxidation peak observed in the first cycle (curve a) which corresponds to Peak IV in Figure $6 \mathrm{~B}$, commences at around $-0.120 \mathrm{~V} v s$. SCE and the curve shows a clear anodic peak at $-0.025 \mathrm{~V} v s$. SCE. This potential peak corresponds to the oxidation of borohydride since the cyclic voltammogram on both Ag-GCE and polycrystalline silver electrode in alkaline solution with no borohydride did not show any oxidation process at this potential. In all the cycles of Figure 7, the potential sweep was reversed at $0 \mathrm{~V} v s$. SCE towards negative potentials; only in the first cycle a cross potential at $-0.065 \mathrm{~V} v s$. SCE was observed (curve a); this behavior might indicate changes on the silver layer, and as mentioned above, possibly due to the losts of some unstable layers of silver. The reverse sweep also shows an oxidation process with low current. In the second cycle (curve $b$ ) the current of the oxidation of borohydride increased by $70 \%$ and shifted towards negative values $(-0.05 \mathrm{~V} v s$. SCE) compared with the first cycle.

It could be speculated that during the first cycle the silver surface partially oxidizes and becomes more catalytically active towards the oxidation of borohydride in the second cycle. In the following cycles the peak potential gradually shifts to positive values and the current gradually decreases until in the $15^{\text {th }}$ cycle the current was $\approx 40 \%$ of that observed in the second cycle and the peak potential $-0.09 \mathrm{~V} v s$. SCE. The low current of these peaks could be due to two factors: less amount of borohydride ions near the electrode surface after the oxidation scan, or adsorption of the oxidation products of borohydride such as borohydroxide or oxide intermediates on the silver catalyst that could block the active sites. This behaviour is similar to the oxidation of alcohols observed on $\mathrm{Ni}$ electrodes by Manriquez et al. (41) where an adsorption step is involved in the oxidation mechanism. The slight shift of the potential peak towards negative values with the number of cycles might be an indication that more silver oxide is formed and favors the borohydride oxidation.

It should be noted that a shoulder (pseudo-wave, V) appears in the second cycle on the scan towards positive values at ca $-0.2 \mathrm{~V} v s$. SCE. The origin of this shoulder has been discussed by Chatenet et al. (20) during the analysis of the borohydride oxidation using both a commercial silver-Vulcan nanostructued electrode and a bulk polycrystiline silver electrode. Using the rotating disc electrode technique the authors mentioned that the "pseudo-wave" is not limited by diffusion-convection and was assigned to the formation of the $\mathrm{OH}^{-}$layer adsorbed on the silver particles. Other authors have observed the adsorbed layer of $\mathrm{OH}^{-}$on the silver (111) crystalline plane (42). They found that the oxidation peaks of $\mathrm{BH}_{4}{ }^{-}$occur at the same potential as the oxidation of $\mathrm{Ag}_{2} \mathrm{O}$. The three anodic peaks observed in the curve a of Figure 6A, i.e. the formation of an $\mathrm{Ag}_{2} \mathrm{O}$ monolayer (peak I) as well as the formation of bulk $\mathrm{Ag}_{2} \mathrm{O}$ (peak II) and $\mathrm{AgO}$ (peak (III), respectively, appear at more positive potentials than the shoulder and peak observed for $\mathrm{BH}_{4}{ }^{-}$oxidation at $-0.2 \mathrm{~V}$ and $-0.05 \mathrm{~V} v$. SCE respectively, as the curve in Figure 7 shows.

Cyclic voltammograms using the GCE modified with silver nanoparticles are shown in Figure 8 extending the limit of anodic potential up to $+0.8 \mathrm{~V}$, where $\mathrm{Ag}_{2} \mathrm{O}$ and $\mathrm{AgO}$ are formed, Figure ( $8 \mathrm{~A}$, peaks I, II y III). With the nanostructured material, the peaks I y II shifted to less positive potentials of ca. $200 \mathrm{mV}$ while peak III appears at the same 

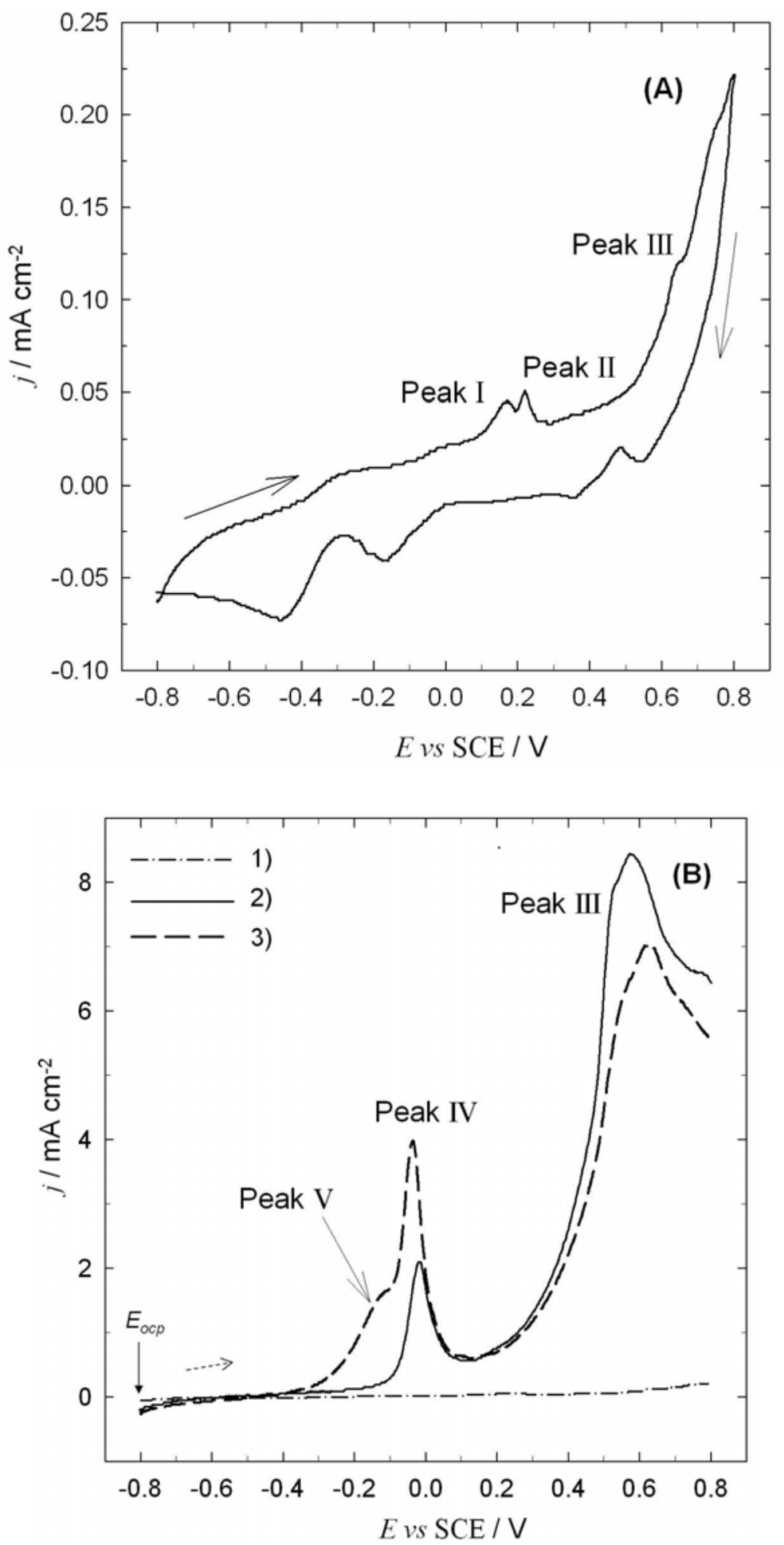

Figure 8.- Linear voltammograms of a nanostructured Ag-GCE electrode of $0.07 \mathrm{~cm}^{2}$ geometrical area in various electrolytes at a potential sweep rate of $0.02 \mathrm{~V} \mathrm{~s}^{-1}$. (A) $1 \mathrm{M}$ $\mathrm{NaOH}$ solution, first cycle, (B) curve $1,1 \mathrm{M}$ of $\mathrm{NaOH}$ curves 2 and 3, same electrolyte plus $10 \times 10^{-3} \mathrm{M} \mathrm{NaBH}_{4}$, first and second scan respectively . $E_{n}=-0.6 \mathrm{~V}, t_{n}=100 \mathrm{~ms}, E_{g}=$ $-0.3 \mathrm{~V}, t_{g}=90 \mathrm{~s}$.

potential. Significant change occurs with the nanostructured material when $\mathrm{BH}_{4}{ }^{-}$was added. On the first scan the peak IV appears at $-025 \mathrm{~V} v s$. SCE and there is no evidence 
of peaks I and II except peak III. On the second scan, peak V appears at $-0.15 \mathrm{~V} v s$. SCE and the potential of peak IV shifted by few milivolts towards cathodic values. The main difference between polycrystalline $\mathrm{Ag}$ and the nanostructurated Ag-GCE is the magnitude of the currents of peak IV, compared with the processes of Ag in the absence of $\mathrm{BH}_{4}^{-}$. For example, in Figures $6 \mathrm{~A}$ and $6 \mathrm{~B}$, the ratio between current of peak IV / current of peak $\mathrm{I} \approx 1.3$, whereas in Figure 7 , this ratio is $\approx 100$. The origin of this difference between solid and nanostructured Ag materials has not been established yet.

\section{Conclusions}

Potential step amperometric techniques (PSA) were used to deposit silver nanoparticles on glassy carbon substrates but showed a relatively low electroactive area per unit of electrode area. The electrodeposition of silver on glassy carbon by PSA gives an unstable outer layer with particles on the micrometer scale and a more stable inner layer with particle sizes between 50 and $200 \mathrm{~nm}$. The behavior of nanostructured material is similar to the bulk silver in an alkaline, $1 \mathrm{M} \mathrm{NaOH}$ aqueous solution, showing three processes of silver oxidation, a difference of $200 \mathrm{mV}$ for the formation of $\mathrm{Ag}_{2} \mathrm{O}$ and $\mathrm{AgO}$ at the same potential.

At the nanostructurated silver deposits, the oxidation of borohydride ion is observed at $-0.025 \mathrm{~V}$ vs. SCE. The cyclic voltammetry experiments showed that the oxidation mechanism involves an adsorption process, and the intervention of $\mathrm{AgOH}$, also.

Glassy carbon electrodes were used as a first step in order to analyze the relationship between the morphological characteristics of Ag nanoparticles and their electrocatalytic behavior towards the oxidation of borohydride. Further studies will utilize RVC and other $3 \mathrm{D}$ electrodes.

\section{Acknowledgments}

The authors gratefully acknowledge the Mexican Academy of Sciences and the Royal Society of the London who sponsored a visit by Dr. A. Alatorre-Ordaz to the University of Southampton, and CONACyT for the visit of V.A. Hernández-Ramírez. Founds for research where provided by the Fondo Mixto CONACyT-Gobierno del Estado de Guanajuato (CONCYTEG) Grant GTO-2007-C01-69453.

\section{References}

1. Energy Statistics Yearbook 2005. United Nations, Department of Economic and Social Affairs.

2. P. Costamagna, S. Srinivasan. J. Power Sourc., 102, 242 (2001).

3. S. Cleghorn, D.K. Mayfield, D.A. Moore, J.C. Moore, G. Rusch, T.W. Sherman, N.T. Sisofo, U. Beuscher. J. Power Sourc., 158, 446 (2006).

4. $\quad$ M.S. Dresselhaus, I.L. Thomas. Nature, 414,331 (2001).

5. W. Vielstich, A. Lamm, and H.A. Gasteiger Handbook of Fuel Cells: Fundamentals, Technology and Applications, Vol. 3., Wiley, New York, (2005).

6. M.R. Tarasevich, Z.R. Karichev, V.A. Bogdanovskaya, E.N. Lubnin, and A.V. Kapustin. Electrochem. Comm., 7,141 (2005). 
7. I.D. Raistrick, US Patent No. 4,876,115 (1989).

8. A. Kundu, J.H. Jang, J.H. Gil, C.R. Jung, H.R. Lee, S.-H. Kim, B. Ku, Y.S. Oh. J. Power Sourc., 170,67 (2007).

9. C. Ponce de León, D. Pletcher, F. C. Walsh, D. J. Browning, J.B. Lakeman. J. Power Sourc., 155,172 (2006).

10. R. Jamard, A. Latour, J. Salomon, P. Capron, A. Martinent-Beaumont. J. Power Sourc., 176,287 (2008).

11. R. Jasinski. Electrochem. Technol., 3,40 (1965).

12. J. Ma, J. Wang, Y. Liu. J. Power Sourc., 172,220 (2007).

13. J.I. Martins, M.C. Nunes. J. Power Sourc., 175,244 (2008).

14. U.B. Demirci. J. Power Sourc., 172,676 (2007).

15. J.I. Martins, M.C. Nunes, R. Koch, L. Martins, M. Bazzaoui. Electrochim. Acta, 52,6443 (2007).

16. G.H. Miley, N. Luo, J. Mather, R. Burton, G. Hawkins, L. Gu, E. Byrd, R. Gimlin, P.J. Shrestha, G. Benavides, J. Laystrom, D. Carroll. J. Power Sourc., 165,509 (2007).

17. C. Ponce-de-León, A. Rose, J.B. Lakeman, D.J. Browning, R.W. Reeve, F.C. Walsh. J. Power Sourc., 164,441 (2007).

18. M.H. Atwan, D.O. Northwood, E.L. Gyenge. Int J Hydrogen Energ, 30,1323 (2005).

19. Cheng, K. Scott. J. Electroanal. Chem., 596,117 (2006).

20. M. Chatenet, F. Micoud, I. Roche, E. Chainet. Electrochim. Acta, 51,5459 (2006).

21. A.Y. Tsivadze, M.R. Tarasevich, V.N. Titova, A.A. Yavich, N.V. Petrova. Dokl. Phys. Chem., 414,107 (2007).

22. $\quad$ R.K. Raman, S.K. Prashant, A.K. Shukla. J. Power Sourc., 162,1073 (2006).

23. E. Gyenge. Electrochim. Acta, 49,965 (2004).

24. B. H. Liu, Z. P. Li, S. Suda. J. Power Sourc., 175,226 (2008).

25. G. Selvarania, S. K. Prashanta, A. K. Sahua, P. Sridhara, S. Pitchumania and A. K. Shukla, J. Power Sources, 178, 86 (2008).

26. U.B. Demirci, J. Power Sourc., 172,687 (2007).

27. J.M. Friedrich, C. Ponce-de-León, G.W. Reade, F.C. Walsh. J. Electroanal. Chem., 561,203 (2004).

28. G. Sandmann, H. Dietz, W. Plieth. J. Electroanal. Chem., 491,78 (2000).

29. M. Ueda, H. Dietz, A. Anders, H. Kneppe, A. Meixner, W. Plieth. Electrochim. Acta, 48,377 (2002).

30. A. Hubin, J. Vereecken. J. Appl. Electrochem., 24,239 (1994).

31. A. Hubin, J. Vereecken. J. Appl. Electrochem., 24,396 (1994).

32. S. Vandeputte, B. Tribollet, A. Hubin, J. Vereecken. Electrochim. Acta, 39,2729 (1994).

33. D. Gonnissen, S. Vandeputte, A. Hubin, J. Vereecken. Electrochim. Acta, 41,1051 (1996).

34. A. J. Bard, L. R. Faulkner. Electrochemical Methods: Fundamentals and Applications, $2^{\text {nd }}$ edn. Wiley, New York, (2001).

35. M. Palomar-Pardavé, M. T. Ramírez, I. González, A. Serruya, B. R. Sharifker; $J$. Electrochem. Soc., 143,1551 (1996).

36. E. Kirowa-Eisner, D. Tzur, E. Gileadi. J. Electroanal. Chem., 621,146 (2008).

37. G.S. Popkirov, M. Burmeister, R.N. Schindler; J. Electroanal. Chem., 380,249 (1995).

38. A. Vaskelis, A. Jagminien, L. R. Juskenas. Electrochim Acta, 50,4586 (2005). 
39. B. M. Jovic and V. D. Jovic, J. Serb. Chem. Soc., 69,153 (2004).

40. E. R. Savinova, D. Zemlyanov, B. Pettinger, A. Scheybal, R. Schlögl, K. Doblhofer. Electrochimica Acta, 46,175 (2000).

41. J. M. Manriquez, S. Gutiérrez, A. Alatorre-Ordaz, F. Bedioui. Anal. Chim. Acta, 378,161 (1999).

42. M. Haruta, M. Daté. App. Cat. A, 222,427 (2001). 